\title{
SUBJECTNESS OF DIGITAL COMMUNICATION IN THE CONTEXT OF THE TECHNOLOGICAL EVOLUTION OF THE CONTEMPORARY SOCIETY: THREATS, CHALLENGES, AND RISKS ${ }^{1}$
}

\section{INTRODUCTION}

The contemporary digitalization of social and political processes is characterized by its high intensity. Moreover, in the context of the COVID-19 pandemic, the transition from traditional social interaction models and formats to digital formats has only accelerated. Today we can, to a certain extent, talk about the so-called forced digitalization, based on the objective need to maintain the social distance between people.

The digitalization trend seems to us today to be global and long-term. Within the framework of this trend, "smart" algorithms and artificial intelligence technologies, as well as self-learning neural networks, which have been rapidly evolving in recent years, are of particular interest.

One of the indicators of such an evolution is a significant increase in the instrumental potential of artificial intelligence in the processing and analyzing big data in the digital space and the formation of the ability to communicate with living people automatically in various spheres of contemporary social life.

As the analysis of current practice shows, the technologies of artificial intelligence and algorithms for self-learning neural networks developed to date already demonstrate the possibilities of successful and, at the same time, independent communication with a person, using for this the analysis of arrays of digital user data and subsequent self-learning.

Simultaneously, artificial intelligence and neural networks technologies are not only evolving but also intensively introduced into the current practice of mass digital communications, penetrating an ever more comprehensive range of spheres of life in contemporary society without requiring any operator control over their work.

To date, technologies of artificial intelligence and self-learning neural networks have learned to independently create and broadcast various content to target audiences

${ }^{1}$ This research has been supported by the Interdisciplinary Scientific and Educational School of Moscow University "Preservation of the World Cultural and Historical Heritage." 
of users, based on their perception of the world around them, the specifics of subjective ideas about socio-political reality, and also taking into account the content and structure of a group and individual semantic models of worldview and behaviour.

Thus, a software algorithm or a software and hardware complex can potentially communicate more effectively with a person, influencing his views, ideas, and behavioural patterns. It is no coincidence that such algorithms are actively used in the digital space by global players (Google, Facebook, Twitter, YouTube, Instagram, Tinder, and others) to achieve their corporate goals (primarily, to maximize the monetization of their platforms through the formation of targeted information flows towards their own users, in connection with which the concept of "platform capitalism" even appeared (Srnicek, 2019).

In the conditions of possessing a monopoly on the information and communication impact on its users, each of these platforms today has powerful capabilities for forming group representations and behavior models in almost any area of human life. In this regard, the worry and attention of government institutions to technology giants in terms of realizing their potential of influence in the social and political sphere was only a matter of time.

At the same time, we are convinced that, despite a series of high-profile scandals involving the use of Facebook and Twitter for political purposes, for example, during the presidential elections in the United States and Brexit in the U.K., artificial intelligence technologies and neural networks will actively develop. Their communication abilities will correspondingly grow, and the technologies themselves will penetrate more and more deeply into the communication processes of social and political interaction of people around the world.

Therefore, it seems to us quite natural that in recent years, much attention of scientists and specialists has been attracted to the topic of using artificial intelligence technologies and neural networks in the socio-political sphere. A significant number of scientific works has been devoted to various aspects of using artificial intelligence in contemporary social and political processes (see. for example: Horowitz et al., 2020; Fedorchenko, 2020; Bykov, 2020; Baecker, 2019; Srnicek, 2019; Larina, Ovchinsky, 2018; Lovink, 2016; Kosinski et al., 2013).

We also consider it extremely important for contemporary scientists in social sciences to analyze the ongoing technological transformations and the digital effects associated with them, some of which may pose a significant threat to social development in general.

Of course, we do not classify ourselves as cyber-pessimists. We assume that with a competent and responsible approach to the implementation of artificial intelligence technologies and neural networks in public and political practice against the background of active digitalization of contemporary society, it is quite possible to receive specific "bonuses" in the form of efficiency, convenience, transparency of the corresponding socio-political interactions between various individuals, social groups, institutions of power, corporations.

However, in our view, the traditional social sphere and the sphere of socio-political communications can be especially sensitive to technological transformations since they are characterized by pronounced semantic, ideological, value, and symbolic components, determining the content processes of social interaction. 
It is around these components that the connected discourse in public policy traditionally unfolds; they are an integral part of traditional public discussions. To what extent are neural network algorithms and artificial intelligence technologies capable of preserving the value-semantic and symbolic content of traditional social interactions without reducing the content components of classical communication interaction? The answer to this question is not apparent today, and we find here certain risks for social development.

Another potential challenge may be the problem of the subjectness of socio-political communications and social interaction. In the case of the active introduction of self-learning software algorithms into traditional social and political communication processes, capable of carrying out independent information and communication interactions with actual users of the digital space, the question arises of determining the real subjects of the corresponding communication acts.

Is a neural network algorithm a full-fledged subject of communication? Whose interests does it represent in the processes of information and communication interaction, independently learning and evolving? How much can a real person be protected from manipulative influence if he does not know or does not even have the opportunity to find out that he is dealing not with the real interlocutor, but with a software algorithm that imitates him? ${ }^{2}$

It seems to us that such issues acquire special meaning in the context of the existence in the online space of global social networks and social media resources, within the framework of which the processes of digital self-communication are actively formed and implemented between users, who are not only recipients of information but also are fullfledged content generators and initiators of communication interactions.

In this kind of digital environment of self-communication, where there are hundreds of millions of creators, distributors, and recipients of information content, the introduction into network communication processes of technological solutions that can simulate an actual user and use artificial intelligence algorithms and neural networks raises the problem of determining the subjectness of communication even more acutely.

Of course, the range of problems, challenges, and risks associated with the digitalization of contemporary society and introducing artificial intelligence technologies and neural networks into the current practice of socio-political interaction is not limited to the questions posed. However, even the problems outlined by us are, in our opinion, important for scientific comprehension. However, even the problems outlined by us are, in our opinion, important for scientific comprehension.

\section{MAIN PERSPECTIVE DIRECTIONS OF COMMUNICATIVE SUBJECTNESS MODELS' DEVELOPMENT}

Before moving on to the problem of subjectness, it is essential to clarify the signs of digital communication that are different from the traditional type of communica-

${ }^{2}$ Moreover, this question seems to us to be quite relevant in a situation where the user knows that his interlocutor is not real, due to the fact that a person tends to anthropomorphize objects with which he interacts. 
tion (newspapers, radio, television). L. Manovich, dealing with this issue (Manovich, 2018: 61-83), gives several signs of digital communication that are important for our research:

- programmability (you can make significant changes to the communication mode through software);

- modularity (new media have a similar modular structure due to algorithmically determined patterns, pixels, etc.);

- automation (standardization of many functions and elements of communication; partial weakening of the creative process, including in political, legislative work);

- variability (elements of new media, instead of identical copies, construct many of their own versions);

- transcoding (everything converts into data, digital content correlates with software, algorithms, but not with human culture, there are risks of cultural reconceptualization in the new reality).

If we talk about social and political subjectness, then the research of this phenomenon was mainly conducted in the field of social sciences. K. Marx associated the subjectness of power with the category of class. Critics of the Marxist approach proposed models of political elites and strata, but no fundamental insights were made in the direction of the phenomenon of subjectness of transforming communications. Russian political scientist V. G. Ledyaev, who analyzed in detail the theory of S. Lukes about the so-called "third person of power," suggested that political power be understood as the ability of a subject to subjugate an object in the sphere of politics, proceeding from his intentions (Ledyaev, 2001: 267-269, 302).

Ledyaev revealed subjectness in recognizing concrete object subordination technologies from the subject (manipulation, persuasion, coercion, impulse, authority, and force). In contrast to the subject, scientists understand the object through the categories of disunity, fragmentation, subordination, and initial passivity. However, there are studies in which the object of power is analyzed in terms of its benefits from submission to the subject of power (Safronov, 2018: 29-33).

As for the issue of studying the phenomenon of subjectness in the context of contemporary digitalization, many authors are skeptical about the role of the Internet in changing subjectness. On the one hand, some scientists believe that the emergence of network communications does not fundamentally change the existing structure of power and society. On the other hand, they still recognize the emergence of the phenomenon of "superpower," which is manifested in some trends (Rodkin, 2016: 62-63): an increase in the number of pseudo-subjects of communication with false social identities, automation of control, dehumanization of communicative techniques, unification of ideas within the framework of virtualization, displacement of the masses on the Internet while securing the "right to reality" as privileges of elites, etc. R. Barbrook saw the so-called "California ideology" as a source of an incorrect approach to the analysis of contemporary subjectness, the supporters of which believed that information technologies will undoubtedly strengthen the individual, his subjectness in opposition to the nation-state (Barbrook, 2015: 38).

The crisis of the traditional subjectness of the citizen is well explained by the Australian researcher S. McQuire in his theory of geomedia. According to this theory, 
geomedia is a new type of media ubiquitous by digital applications and gadgets that penetrate everyday life and are associated with geolocation practice (McQuire, 2018: 35 ). Geomedia creates conditions when citizens must constantly defend the publicity of the political space, fight for such signs of their subjectness as confidentiality and the right to refuse compulsory biometrization.

Nowadays, the most significant problem is the lack of thorough interdisciplinary research of subjectness in communications, power, and a small amount of research at the junction of the theory of neural networks, artificial intelligence and political science, sociology, and other sciences. Until now, theoretical and methodological disputes in the "camp of natural sciences" and similar conceptual battles in the "camp of social sciences" have worked on the principle of closed echo chambers, practically without overlapping with each other. As a result, representatives of both intellectual "camps" missed such a phenomenon as self-communication, which is unrelated to subjectness's social nature.

In general, we can identify several areas where there is a serious prospect of developing a model of subjectness in the context of the emerging phenomenon of selfcommunication.

Firstly, the most active driver of contemporary developments in neural networks and artificial intelligence is the "service-technological direction."

The state is interested in creating digital platforms and those innovative tools of mass communication that will:

- meet the growing demands of citizens for various kinds of services within the framework of the e-government paradigm, its web applications, and portals;

- solve the tasks of national security, countering terrorism, crime, and corruption;

- perform analytical tasks (conducting complex research, forming statistical databases, detecting correlations, causal relationships in the behaviour of citizens).

The service-technological direction, as a form of symbiotic relations between the contemporary state and IT corporations, continues to develop within the framework of the concept of "state as a platform" proposed at the time by A. Helmond, who equated government policy with the service sector (Helmond, 2015). Through this approach's prism, the most significant interest is represented by two trends in contemporary communications - avatarization and interfaceization.

First, avatarization as a massive distribution of digital avatars among actual people was directly due to the service approach of digital platforms. To receive any service, and most importantly, to gain the right to access the communication process itself, a person needed to "upload" part of his personality data into a digital avatar on the appropriate digital platform. Thus, at the turn of the 21 st century, subjectness acquired its communication form in the form of a digital avatar.

Another aspect of avatarization was the emergence of digital avatars of "virtual officials" and "virtual politicians." However, almost immediately, there were risks of false digital avatars, whose artificial intelligence was tasked with imitating the activity of both actual people and their official "virtual representatives." The accompanying process of interfaceization was associated, on the one hand, with the introducing standard algorithms, functional templates for the user of a digital avatar, on the other hand, with imposing digital rituals - standardized models of user behaviour when using an 
avatar in the communication process (likes, dislikes, posts, reposts, viewing news, selfies, comments, life-broadcast, etc.).

The second research direction is associated with the Media Richness Theory, which gained its fame thanks to the works of R. Lengel and R. Daft, who suggested that rich and varied information should reach a person through the same diverse communication technologies (Daft, Lengel, 1986). Despite criticism of this theoretical model, contemporary political science works have appeared that use the concept of media capabilities to analyze the use of chatbots with artificial intelligence on e-government resources (Androutsopoulou, Karacapilidis et al., 2019). It is logical to predict an increase in the volume of such intelligent bots shortly - businesses are interested in this since their interaction improves the quality of services through flexible personalization of settings when communicating with potential customers.

The Media Richness Theory, in principle, correlates with the Law of Requisite Variety by W. Ashby, which states that effective management is possible when the diversity of management techniques on the part of the subject matches the diversity of the controlled object. However, much earlier, a similar analytical scheme was considered by the Russian scientist A. A. Bogdanov (Loktionov, 2016).

In fact, Bogdanov described the properties of network communications before the era of the Internet, calling them "a network of threads," highlighting the central "egression" and the "degressive associations" that strengthen it. Suppose in place of these Bogdanov categories we put a political actor (a representative of the elite, the state, the ruling party) and bots subordinated to his interests but simultaneously capable of self-communication based on artificial intelligence. In that case, we get a unique hybrid subjectness, the purpose of which is the same classical subordination of object management.

Hybrid subjectness is interesting in that it actually masks and hides from citizens an actual actor who is carrying out the political and administrative process by imitating human communication with technologies, algorithms of neural networks, and artificial intelligence. It is enough to imagine that the moderators of virtual communities and active participants in social networks will, in fact, be bots that will begin to communicate with each other, initiate discourse, construct and disseminate fakes, put likes and dislikes, comment on videos, "troll" a political opponent, influence the political the agenda.

The theoretical framework of hybrid subjectness fits well the very insightful ideas of I.A. Isaev on the so-called "megamachine of power." In his opinion, this "machine" was initially primarily a mythological concept about a certain order at the dawn of human history. This "machine" was created for applied tasks - the gradual expansion of power over people and nature through various components - political, economic, military, bureaucratic. Nevertheless, its most important feature, according to Isaev, was management technologies based on manipulating numbers. Thus, both archaic and contemporary management technologies were guided by the same maxim "number is the rational basis of the political" (Isaev, 2019).

The third research area can be conditionally called "axiological." Those who follow this approach associate the subjectness of artificial intelligence with the possibilities and risks of "value programming and reprogramming" (Baghdasaryan, 2019). 
D. S. Zhukov, highlighting a special "political intellect" (in the form of its applications in the political sphere), analyzes in detail the social trust rating system on the example of China, whose supporters appeal to the values of justice (Zhukov, 2020).

Thus, we can note that the evolution of artificial intelligence technologies and their potential application in the socio-political sphere are a very actively developed scientific problem for a long time by scientists and specialists, which today does not have a straightforward solution and a universal approach.

\section{KEY ISSUES IN THE DEVELOPMENT OF ARTIFICIAL INTELLIGENCE TECHNOLOGIES AND NEURAL NETWORKS IN THE SOCIAL SPHERE}

As the analysis of the current practice of digitalization demonstrates, contemporary technologies will allow soon to replace the individual with a neural network algorithm, the function of which will be the implementation of information and communication activities on behalf of an actual user based on the analysis of user preferences and his previous experience assimilated by artificial intelligence. In fact, nothing prevents neural network algorithms from communicating on behalf of various actors in their social interaction processes.

Already today, we see examples of how neural network algorithms produce content in various areas of society. In 2017 the project Neurona was presented - an album created by a neural network based on the analysis of Kurt Cobain's musical compositions. In 2018, using a neural network, a piece of music, "Digital Sunrise," was written, later performed by the orchestra under the direction of Y. Bashmet. In 2017, the painting "Portrait of Edmond de Belamy," created by a neural network algorithm, was sold at Christie's auction. Today, neural networks are also trained to write movie scripts, create story texts, i.e., artificial intelligence begins to claim a certain subjectness in creativity.

However, the use of neural network algorithms is not limited exclusively to the field of creativity. Obviously, their potential will be actively used in other spheres of society, including social, economic, and political. ${ }^{3}$

As Sean Gourley rightly notes, "artificial intelligence and learning algorithms will make it almost impossible to tell robots from humans - and actual news from fake. And we will see the emergence of more automated computational propaganda - bots using sophisticated artificial intelligence frameworks, removing the need to have humans operate the profiles. Algorithms will not only read the news but write it. These stories will be nearly indistinguishable from those written by humans. They will be algorithmically tailored to each individual and employed to change their political beliefs or to manipulate their actions" (Gourley, 2015).

At the same time, interactions will not necessarily use the "human-neural network" format exclusively. It is potentially possible to implement the "neural network-neural network" format, within which a person remains outside the framework of the com-

${ }^{3}$ Today we can analyze the corresponding cases. For example, in Israel, a neural network algorithm was developed for making court decisions based on the analysis of arrays of simple cases over several years with a clear context of incidents for which binary decisions are made - either a fine or 15 days of arrest. 
munication process. When such a scenario is realized, the phenomenon of self-communication arises, in which there are no actors as such, since software algorithms replace them.

We especially note that neural networks can be trained not only within the framework of a person's logic and on his experience, as a result of that the value-semantic content created by them may turn out to be absolutely unrelated to the interests, needs, and values of a person. ${ }^{4}$ In this regard, the question of how the freed from "manual control" algorithms of neural networks will evolve seems to be important.

In this regard, Microsoft's experiment on implementing the Tay neural network complex with emotional intelligence elements in the Twitter microblogging service is very indicative. As a result of self-study, based on the analysis of the results of network interactions with actual Twitter users, Tau became "radicalized" and, as a result, began to spread radical ideas, supporting Hitler's policies and genocide, and also insulting feminists.

Extremely unsatisfactory results were also obtained when training an artificial intelligence in the framework of a similar project of Chinese specialists $(\mathrm{Xu}, 2018)$. The developed bots (Xiao Bing and BabyQ) began to demonstrate a critical position concerning the current political regime in the country.

These precedents show the risks of value learning of artificial intelligence within the traditional human-bot interface framework. Suppose that neural networks' algorithms will be "admitted" to the practice of digital communications in the socio-political sphere. What ideas, values, and meanings will broadcast in the digital space to actual users who are unaware that they are not communicating with a living person, but only with artificial intelligence? To what extent will a person be able to cope, due to his exclusively human abilities, with neural networks that analyze a communication partner? To what extent can a human personality be able to resist the software algorithm on an equal footing in the framework of communication interaction both with him and with each other? ${ }^{5}$ What will be the manipulative potential of neural networks that, based on the analysis of personal digital traces, can impact a person's consciousness who is convinced that he is communicating not with artificial intelligence but with an actual person? The answers to these questions seem to be open.

\section{CYBER SIMULACRA AND DIGITAL INFORMATION CAPSULES}

Already today, the analysis of contemporary communicative practice in the Internet space shows that in recent years, "smart" virtual structures are increasingly used in self-communication processes. These virtual structures are being intensively intro-

${ }^{4}$ As an example, we will give the opposition of the neural network algorithm AlphaGo and AlphaZero. If AlphaGo was taught to play Go based on studying the games played by people, then AlphaZero played with itself during the self-learning process, knowing nothing about the human experience. As a result, the AlphaZero algorithm, which was not based on human knowledge, beat the best algorithm based on human experience (AlphaGo) with a score of 100: 0 .

${ }^{5}$ For example, the Tinder platform uses artificial intelligence algorithms to form connections between users based on the analysis of their social characteristics. The social network Facebook generates personal news feeds for its members based on the analysis of their digital footprints. 
duced into the communication space to organize mass user discussions and manage them in the space of social networks, making it possible to form the effect of public opinion influencing online users' consciousness.

Gradually, the digital space of mass self-communications is more and more filled with manipulative and propaganda content, and virtual constructions began to play a significant role in the processes of influencing mass consciousness on the Internet, acting as initiators and active participants in mass discussions related to the analysis and interpretation of socio-political phenomena and events, as well as the development of collective meanings in the processes of online self-communication (Bazarkina, Pashentsev, 2019).

As part of considering this problem, we have developed the concept of a cyber simulacrum - a virtual artificially constructed pseudo-personality that functions in the Internet space and simulates the representation of an actual network user (Volodenkov, 2019).

It seems to us a highly likely scenario in which the potential for the influence of "smart" cyber simulacra on mass consciousness will increase as artificial intelligence technologies and self-learning neural networks improve. Surrounded in the space of social networks by cyber simulacra that simulate actual users, as well as neural network algorithms that generate personalized content based on personality analysis, a person finds himself in a digital information capsule, in which the subjects of communication are not clear, and in many cases are simulated (Volodenkov, 2019).

Moreover, within such a capsule framework, a person becomes only a controllable object of the technological formation of beliefs, meanings, ideas about social and political reality (Lovink, 2016).

An information capsule means for us an information structure within which peculiar ideas, symbols, meanings, beliefs, and opinions circulating in its closed space do not change due to critical comprehension of information and perception of alternative explanatory models. On the contrary, these ideas, symbols, meanings, beliefs, and opinions are only preserved, self-supported, consolidated, and even strengthened through repeated repetition, discussion, approval among like-minded people (Volodenkov, 2019).

It is quite difficult for a participant to get out of such an information capsule. At the same time, the motives and incentives to go beyond it simply do not arise due to the social comfort of being in it along with the same like-minded people. Artificial intelligence systems may well reinforce and enhance such effects. This is fraught with the substitution of the model of persuasion, argumentation with the model of constantly renewing manipulative socio-technologies, focused on reproducing the existing order and ignoring the subjectness and opinion of the citizen (Kamassa, 2012).

Moreover, given the fact that online communities are largely socially differentiated in various parameters, the effect of capsulation, in our opinion, is only reinforced, reducing the permeability of group information capsules, which only strengthen the value-semantic and symbolic frameworks with the help of commentary activity of like-minded persons (Petrov, Proncheva, 2018).

We deliberately introduce the term "information capsule" in order to emphasize in this process the presence of an information structure and the corresponding informa- 
tion and communication space, and not just the echo chamber effect, which K. Sunstein originally wrote about.

Attention is drawn to the fact that cyber simulators used for information capsulation are becoming more and more realistic in the visual aspect every day. Deep learning algorithms have learned how to create portraits of non-existent people effectively. For manipulative and propaganda purposes, they can quickly form any person's image (both real and fictional) and carry out pseudo-subject communication on his behalf in public space.

In this regard, it is necessary to pay attention to the Deepfake technology based on synthesizing a human image and voice based on artificial intelligence (Waddel, 2018). Such content can be very realistic and can be used to manipulate political processes globally and influence certain target groups of people (Palmer, 2020).

\section{DIGITAL AVATARIZATION AND DIGITAL INTERFACES}

Digital avatarization does not mean only the distribution of accounts of actual people to connect them to the communication process but also the emergence of digital avatars of virtual personalities based on artificial intelligence. For example, in the United States, a "virtual official" Emma was created, ${ }^{6}$ which can process about half a million Americans' requests in two languages - Spanish and English (Fedorchenko, 2020). This kind of chatbots "officials," operating based on artificial intelligence technologies, help government officials to process a massive amount of information and have appeared in Dubai, India, China, Argentina, Australia, Singapore, Great Britain, Germany, and other countries.

"Virtual politicians" are also being actively introduced into current political practice. For example, in New Zealand, the SAM project was developed based on artificial intelligence, which conducted dialogues with users on social networks, preparing for the general elections in 2020. Artificial intelligence Michihito Matsuda was developed in Japan. This system had its own electoral program and came in third in Tama's elections (part of the Japanese capital) with 4,000 votes. However, what will happen to society if the bots of "virtual politicians" and "virtual officials" completely switch to self-communication mode, interacting with people only when necessary through their anthropomorphic digital avatars? ${ }^{7}$

We should also pay special attention to the fact that in the contemporary digital communications practice, we are increasingly faced with the formation of an interface, within which, during independent communication, not unique features, personal interests, but some "communication standards" begin to be considered. The political interface created by the algorithms of neural networks and using artificial intelligence developments acquires the character of a "power machine" with the functionality of universalization and standardization.

${ }^{6}$ U.S. Citizenship and Immigration Services. https://www.uscis.gov/tools/meet-emma-our-virtual-assistant.

${ }^{7}$ It is noteworthy that the American company Avaya has already announced the creation of the first platform for chatbots, thanks to which they will be able to interact with each other to improve their efficiency and expand users' capabilities. 
Such an interface manifests itself in creating, disseminating, strengthening, and imposition of special digital rituals - universal types of human activity in Internet communications. As digital rituals continue to evolve in the context of the formation of self-connection, they actually blur the line between the activity of cyber simulacra based on artificial intelligence and the activity of actual people, as a result of which a person loses subjectness in the digital space (Fedorchenko, 2020).

Scientists have long noticed the phenomenon of asymmetry of the "man-machine" interface. To compensate for the limited access of computers and intelligent technology to human actions, the developers initially created a system design that would partially force users to perform a certain sequential steps procedure. The political itself in such an interface is formed due to the emergence of avocation (C. Chesher's term) - specific conditions that induce actual people as integral actants to become an integral part of the whole technological system of a socio-material nature (G. Lovink in his "Critical Theory of the Internet" writes about a similar phenomenon of the socio-technical system). In this system, invocations arise - actions that determine the parameters of communication, as well as evocations - systemic changes affecting material life and avocations (Sachmen, 2019: 184, 408).

\section{THE PHENOMENON OF ALGOCRACY}

The phenomenon of algocracy (Aneesh, 2006) - algorithmic control or algorithmic power - has certain risks for traditional subjectness. Algocracy results from the gradual acquisition of the classical power of the nature of an algorithm that establishes the conditions, limits of communication, introduces rating indicators that penetrate and control almost all aspects of a contemporary citizen's life - from taxes and issuing certificates to his physical movements. In fact, the algorithmicization of power is the basis of the digital interface of a contemporary political regime, capable of controlling the political agenda within the country, influencing public opinion, maintaining digital sovereignty, and repelling information attacks from other political regimes. Algorithmic power is the foundation of this new reality. Its difference from traditional power is that it rests, on the contrary, in social networks on the "principle of the threat of invisibility" of the individual's actions and not on the "principle of the threat of visibility" (Bucher, 2012). The example of deleting D. Trump's accounts showed this perfectly. This circumstance, in many respects, forces us to rethink the model of disciplinary power by M. Foucault.

As M. Hildebrand writes, algorithmic regulation can be seen in the example of the emergence of digital monitoring (video recording, biometrics), setting standards through computational algorithms (Hildebrandt, 2018). Algorithmization of the subject of power already exists in the legal field, where software and data services can check bank accounts, income, various assets, and real estate. In other words, a government representative makes a decision based on the analytics received thanks to algorithms. The role of algorithms in digital communication is growing so much that it becomes a determining factor in social relations (Beer, 2017). It is no coincidence that Hildebrand raises an important question, is algorithmic regulation capable of replacing legal regulation, and to what extent is this justified? 
Interfaceization is characterized by the fact that the political regime no longer needs to follow the citizens directly - digital corporations do an excellent job with this function. Corporations unconditionally benefit from this symbiotic relationship with the regime, shielding themselves from the unwanted competition and making a profit in the form of user data. Whereas political regimes relieve themselves of their responsibility to society, transferring dissatisfaction with the organization and maintaining communication processes to digital corporations. Thus, the subject of power is disguised behind multiple intermediaries from digital firms. The configuration of power is changing. Perhaps, for this reason, papers on the risks of digital totalitarianism are gradually emerging (Diamond, 2019).

There is no clear understanding yet whether the algocracy will be able to resist the movement of "smart citizenship" (Zandbergen, Uitermark, 2020). For example, the "cybernetic citizenship" model is based on liberal ideology, which uses the practice of civic insights rather than general discourse - the individual awareness of the existing social problems of the urban community by any citizen. This liberal model is focused on creating a stable subjectness in any active citizen, who must have the ability to select information independently. The second model, "republican smart citizenship," is more conservative and proceeds from the reliance of a citizen on scientifically reasoned data, thanks to which he has a position on certain socio-political problems.

Practice shows that the concept of a smart city, designed to make the life of a citizen more convenient and safer, as well as to establish a transparent relationship between him and the government, in fact, turns into an asymmetric nature of access to information (McQuire, 2018: 45, 63, 124). Most of the information about the movement, actions of citizens goes to new centers of city authorities. The whole city turns into the data of the operational archive, access to which is processed by digital corporations and through them - by political regimes. The possibilities of a citizen as a subject of the political process are becoming rather limited and accessible only within the framework of e-government and a small number of politically active communities of social networks.

\section{HYBRID SOCIO-TECHNICAL ORDER}

If we consider the hypothesis that the peak of globalization has passed (Zhukov, 2020), essential information and communication systems will soon be localized in the form of "national zones" of various political regimes. At this stage of avatarization, a deeper interfaceization can occur, which will end with the construction of its own political interface around each political regime from standardized and mandatory rules of communication.

As a result, the final "capture" by political interfaces of digital avatars of their own citizens is possible through the standardization of neural network algorithms and the unification of the rules of communication "citizen - citizen," "citizen - power," "citizen - machine" in applications, portals, communities. Such a socio-technical order can be based on the mechanism of self-communication, when many tasks of political parties, ministries, organizations are transferred to intelligent systems that interact with 
each other on the principles of self-communication. A party, a ministry, or a specific political leader, already incapable of processing a massive amount of information in the new socio-technical conditions and forced to use bots' services, acquire a hybrid subjectness inevitably.

The subordination of citizens' avatars to digital interfaces can be seen in the example of a number of countries. For example, in China, the Social Credit Systems (SCS) project has all the features of such a digital interface (Kostka, 2019). The system ranks citizens based on artificial intelligence technologies, but it is not the government responsible for its implementation, but digital corporations - Alibaba, Tencent, SenseTime, Baidu. This shows that a hybrid state-corporate form is replacing the former subjectness. As a result, trustworthy citizens are on the red lists, and unreliable ones are on the black lists. However, digital interfaces based on the rating of citizens are introduced by private companies in other countries as well (Wong, Dobson, 2019) (see table).

Table 1

Hybridization of Subjectness

\begin{tabular}{||l|l||}
\hline \multicolumn{1}{|c||}{ State } & A corporation that develops a citizen-rating digital interface \\
\hline Germany & Schufa \\
\hline USA & FICO, Affirm \\
\hline Australia & Lodex \\
\hline China & Alibaba, Tencent, SenseTime, Baidu, etc. \\
\hline
\end{tabular}

Against this background, several fundamental questions arise again. First, how a citizen can maintain independence in the choice of digital content in information consumption processes is becoming relevant. Alternatively, the choice for him will be made by artificial intelligence, which functions both within the framework of online resources and social networks in the Internet space, and directly on personal smart devices belonging to a specific person.

By analyzing user activity and personal data, artificial intelligence can independently choose and propose targeted sources of information, publications, events, the most attractive politicians, and parties, based on the person's characteristics and preferences (Kosinski et al., 2013). For example, today, neural facial recognition technology can expose political orientation from realistic facial images with a high probability (Kosinski, 2021). Besides, artificial intelligence can also promote targeted content to set the agenda and manage an event's importance (Horowitz et al., 2018).

If such a scenario is implemented, it is possible to predict with a high degree of confidence a significant decrease in the degree of independence of people in the processes of individual information consumption, as well as the losing skills and competencies of conscious work with information and the formation of reliable ideas about reality.

Quite remarkable in this regard are the statements of the ex-director of Google Eric Schmidt on this matter: "We do not need you to type at all. We know where you are. We know where you have been. We can more or less know what you are thinking about [...] I actually think most people do not want Google to answer their questions [...] They want Google to tell them what they should be doing next [...] If you have some- 
thing that you do not want anyone to know, maybe you should not be doing it in the first place $[\ldots]$ We know everything you are doing, and the government can track you $[\ldots]$ We will know your position down to the foot and down to the inch over time... Your car will drive itself, and it is a bug that cars were invented before computers ... you are never lonely ...you are never bored ...you are never out of ideas" (Watson, Jones, 2013).

The problem is that the creators of artificial intelligence technologies and neural network algorithms have interests in politics, economics, and global governance (Howell, 2011). These interests can significantly affect the substantive aspects of the functioning of artificial intelligence and neural networks in the digital communications space. Moreover, we do not exclude the implementation of a scenario according to which there can be quite a lot of such key players in the field of artificial intelligence, and the relationship between them can be not only competitive but even antagonistic.

Such antagonism, accompanied by an acute clash of interests, can manifest itself in the competition for people's minds in the digital space, where various technological solutions based on artificial intelligence and neural network algorithms are designed to realize the goals of different actors. We can assume the likelihood of forming such a hqhybrid communication space, where an ordinary person will only become a victim of a collision and confrontation between various stakeholders who can create and apply technological solutions based on artificial intelligence and neural networks.

The purpose of such a struggle and competition is to turn people into mass carriers of specific ideas, perceptions, and behaviour models that meet the interests of one or another global (or regional) actor. Today, experts are already discussing the possibility of creating appropriate synthetic information products based on the joint use of Big Data, complex artificial intelligence algorithms, and psychological impact technologies. Such integrated products may contain software modules that encourage people to perform actions already programmed and expected from them (Pashentsev, 2019).

Simultaneously, the possibility of targeting the victim should be noted, which is exposed to the necessary informational influence. Such targeting can be carried out effectively, not only based on classical socio-demographic characteristics. The manipulative effect itself can remain invisible up to direct information and communication contact with the victim. An example is DeepLocker, a novel class of highly targeted and evasive attacks powered by artificial intelligence (Kirat, Jang, Stoecklin, 2018).

\section{CONCLUSIONS}

Summing up the results of this study, it is necessary to draw some conclusions. First of all, we should note that artificial intelligence and neural networks have both constructive and destructive potential, like any other technology created by man. However, this potential is formed mainly within the framework of those semantic paradigms that set meaningful vectors for using digital technologies in contemporary socio-political and social development. 
Obviously, within the platform capitalism paradigm framework, the technologies we consider will be used primarily to make a profit, changing user behaviour according to customers' interests of information and communication impact. In turn, within the framework of the tracking capitalism paradigm, the arsenal of digital technologies will be primarily focused on the collection, processing, and analysis of big data arrays created based on tracking the user activity of citizens in the network and allowing to form a digital portrait of a person for subsequent management.

It seems that a human is the leading creator of the vectors of technological development at this stage of human civilization development. How new digital tools will be applied, what interests, values, and meanings will determine technological evolution, whether digitalization will be humanistic, depends on man. In this regard, the active introduction of artificial intelligence technologies and self-learning neural networks in various spheres of life of a contemporary state and society, in our opinion, is inevitably associated with the emergence of both a wide range of opportunities in the field of democratization of contemporary states and social development, as well as with the formation of several potential threats, risks, and challenges for contemporary society.

This provision seems to us especially relevant in the political and social spheres, which traditionally were and remain today the basis for society's existence and development. Whether a person will lose his subjectness in the conditions of the emerging digital society? Whether he can preserve his subjectness in the space of socio-political interactions, not lose his role in forming values, meanings, and ideas that determine the substantive characteristics of human civilization's existence? It depends, in our opinion, not on technology but exclusively on the person himself.

In our opinion, this is the primary global challenge of our time in the aspect of technological transformations of the traditional social and political space. It is evident that in the event of one of the unfavourable scenarios, humanity may face critical irreversible transformations if the function of the subject of forming values, ideas, and meanings in the digital world will take over an artificial intelligence or elite groups that control it and use it to realize their interests.

We see the main spectrum of current key threats, risks, and challenges for contemporary society precisely in the plane of a person's possible loss of his subjectness, which with a high degree of probability can lead to a reduction in the individual's capabilities in the processes of understanding the world and in the formation of objective perception of reality, as well as to a decrease in a person's ability critically perceive and evaluate the world around us.

As one of the extreme, but at the same time quite probable scenarios of technological development, we admit such a reduction of society in which self-learning neural networks and artificial intelligence algorithms will communicate with each other on behalf of individuals based on the study and analysis of their individual digital profiles, while not only without their participation but also with their consent, thereby forming social norms in which a person will be excluded from traditional social interaction under the auspices of his individual safety and personal comfort. ${ }^{8}$

${ }^{8}$ At the same time, we admit that this kind of communication practices can be carried out not only between different neural network resources but also within a single neural network space that 
As for the political sphere, here, in our opinion, there is significant potential for the use of artificial intelligence technologies and self-learning neural networks in the processes of establishing digital control regimes and digital dictatorships based on manipulating the mass consciousness and on limiting the citizen's abilities (including the ability to receive objective social and political information freely, as well as share it with other citizens without restrictions and legitimate violence from the state in the event of unauthorized communication activity).

On the one hand, it is important to concretize the signs of traditional subjectness that existed before the era of forced digitalization: the presence of classical subjectobject socio-political relations, where the state, its political elites, political leaders, parties, and their ruling coalitions act as the subject of power, and social groups and citizens act as the object of power. At the same time, the vertical, hierarchical nature of relations remains, which determines the formalized framework of political control, the consolidation of power, and other resources in the hands of specific actors.

On the other hand, forced digitalization lays the conditions for the evolution of classical subject-object relations towards disguising the subject of power (state, elite) behind numerous intermediaries between him and civil society in the form of digital corporations (Google, Apple, Huawei, Yandex, etc.), decentralized political administration.

Moreover, the new subjectness introduces certain contradictions in the evolution of digital communications themselves: citizens can use the network effects of digital platforms, creating crowdfunding, democratic projects, and participating in management processes. However, the effect of algorithmic power restricts this kind of initiative, leaving subjectness for the actor who has access to algorithms used by citizens of digital platforms.

In this regard, we would like to conclude our work with the prophetic words of Benjamin Barber that "if we measure power by the potential for monopoly and control over information and communication, it is evident that the new technology can become a dangerous facilitator of tyranny. Even in the absence of conscious government abuse, this potential can constrict our freedom, encroach on our privacy, and damage our political equality. There is no tyranny more dangerous than an invisible and benign tyranny, one in which subjects are complicit in their victimization, and in which enslavement is a product of circumstance rather than intention. Technology need not inevitably corrupt democracy, but its potential for benign dominion cannot be ignored" (Barber, 1998).

\section{REFERENCES}

Androutsopoulou A., Karacapilidis N., Loukis E., Charalabidis Y. (2019), Transforming the communication between citizens and government through AI-guided chatbots, "Government Information Quarterly”, Vol. 36, No. 2, https://doi.org/10.1016/j.giq.2018.10.001 (26.01.2021).

provides "communication" between its users within a single digital platform, comfortably "encapsulating" users within a single resource. 
Aneesh A. (2006), Virtual Migration: The Programming of Globalization, Durham, NC-London.

Baecker R. M. (2019), Computers and Society: Modern Perspectives, Oxford.

Bagdasaryan V. E. (2019), Zagljanut'za chertu. Iskusstvennyj intellekt i postchelovek: problema cennostnogo programmirovanija, Moskva.

Barber B. (1998), Three Scenarios for the Future of Technology and Strong Democracy, "Political Science Quarterly", Vol. 113, No. 4, https://doi.org/10.2307/2658245 (26.01.2021).

Barbrook R. (2015), Internet-revoljucija: ot kapitalizma dotkomov k kiberneticheskomu kommunizmu, Moskva.

Bazarkina D., Pashentsev E. (2019), Artificial Intelligence and New Threats to International Psychological Security, "Russia in Global Affairs", Vol. 17, No. 1, https://doi.org/10.31278/18106374-2019-17-1-147-170 (26.01.2021).

Beer D. (2017), The social power of algorithms, "Information, Communication \& Society", Vol. 20, No. 1, https://doi.org/10.1080/1369118X.2016.1216147 (20.07.2021).

Bucher T. (2012), Want to be on top? Algorithmic power and the threat of invisibility on Facebook, "New Media \& Society", Vol. 14, No. 7, https://doi.org/10.1177/1461444812440159 (20.07.2021).

Bykov I. A. (2020), Iskusstvennyj intellekt kak istochnik politicheskih suzhdenij, "Zhurnal politicheskih issledovanij”, Vol. 4, No. 2, https://doi.org/10.12737/2587-6295-2020-23-33 (26.01.2021).

Daft R .L., Lengel R. H. (1986), Organizational information requirements, media richness and structural design, "Management Science", Vol. 32, No. 5.

Diamond L. (2019), The Road to Digital Unfreedom: The Threat of Postmodern Totalitarianism, "Journal of Democracy", Vol. 30, No. 1, https://doi.org/10.1353/jod.2019.0001 (20.07.2021).

Fedorchenko S. (2020), Fenomen iskusstvennogo intellekta: grazhdanin mezhdu cifrovym avatarom i politicheskim interfejsom, "Zhurnal politicheskih issledovanij", Vol. 4, No. 2, https://doi. org/10.12737/2587-6295-2020-34-57 (26.01.2021).

Gourley S. (2015), Get ready for the robot propaganda machine, http://www.wired.co.uk/article/ robot-propaganda (26.01.2020).

Helmond A. (2015), The platformization of the Web: Making Web Data Platform Ready, "Social Media + Society", Vol. 1, No. 2, https://doi.org/10.1177\%2F2056305115603080 (26.01.2021).

Hildebrandt M. (2018), Algorithmic regulation and the rule of law, "Philosophical Transactions of the Royal Society A: Mathematical, Physical and Engineering Sciences", Vol. 376, Iss. 2128, https://doi.org/10.1098/rsta.2017.0355 (20.07.2021).

Horowitz M. C., et al. (2018), Artificial intelligence and international security, Center for a New American Security (CNAS), Washington, https://www.cnas.org/publications/reports/artificial-intelligence-and-international-security (26.01.2021).

Howell A. (2011), Madness in international relations: psychology, security, and the global governance of mental health, London.

Isaev I. A. (2019), Tehnologii vlasti. Vlast'tehnologii, Moskva.

Kamassa M. (2012), Socio-political manipulation - incidental pathology or immanent component of international realm?, "Przegląd Strategiczny", No. 2.

Kirat D., Jang J., Stoecklin M. (2018), DeepLocker - concealing targeted attacks with AI locksmithing, https://www.blackhat.com/us-18/briefings/schedule/\#deeplocker---concealing-targetedattacks-with-ai-locksmithing-11549 (26.01.2021).

Kosinski M. (2021), Facial recognition technology can expose political orientation from naturalistic facial images, "Scientific Reports", No. 100, https://doi.org/10.1038/s41598-020-79310-1 (20.07.2021). 
Kosinski M., Stillwella D., Graepel Th. (2013), Private traits and attributes are predictable from digital records of human behavior, "Proceedings of the National Academy of Sciences of the United States of America", Vol. 110, No. 15, https://doi.org/10.1073/pnas.1218772110 (26.01.2021).

Kostka G. (2019), China's Social Credit Systems and Public Opinion: Explaining High Levels of Approval, "New Media \& Society", Vol. 21, No. 7, https://doi.org/10.1177/1461444819826402 (20.07.2021).

Larina E., Ovchinskiy V. (2018), Iskusstvennyj intellekt. Bol'shie dannye. Prestupnost', Moskva.

Ledyaev V. G. (2001), Vlast': konceptual'nyj analiz, Moskva.

Lewis M., Yarats D., Dauphin Y. N., Parikh D., Batra Dh. (2017), Deal or No Deal? End-to-End Learning for Negotiation Dialogues, "Proceedings of the 2017. Conference on Empirical Methods in Natural Language Processing".

Loktionov M. V. (2016), A. A. Bogdanov kak osnovopolozhnik obshhej teorii system, "Filosofija nauki i tehniki", Vol. 21, No. 2, https://doi.org/10.21146/2413-9084-2016-21-2-80-96 (26.01.2021).

Lovink G. (2016), Social media abyss: critical internet cultures and the force of negation, Cambridge.

Manovich L. (2018), Yazyk novykh media, Moskva.

McQuire S. (2018), Geomedia: setevye goroda i budushchee obshchestvennogo prostranstva, Moskva.

Minsky M. (2018), Soobshhestvo razuma, Moskva.

Neff G., Nagy P. (2016), Talking to Bots: Symbiotic Agency and the Case of Tay, "International Journal of Communication", Vol. 10, https://doi.org/1932-8036/20160005 (26.01.2021).

Palmer A. (2020), Experts warn digitally-altered 'deepfakes' videos of Donald Trump, Vladimir Putin, and other world leaders could be used to manipulate global politics by 2020, https:// www.dailymail.co.uk/sciencetech/article-5492713/Experts-warn-deepfakes-videospoliticians-manipulated.html (26.01.2021).

Pashentsev E. (2019), Zlonamerennoe ispol'zovanie iskusstvennogo intellekta novye ugrozy dlja mezhdunarodnoj informacionno-psihologicheskoj bezopasnosti i puti ih nejtralizacii, "Gosudarstvennoe upravlenie. Jelektronnyj Vestnik", No. 76, https://doi.org/10.24411/2070-13812019-1013 (26.01.2021).

Petrov A., Proncheva O. (2018), Modeling Propaganda Battle: Decision-Making, Homophily, and Echo Chambers, "Artificial Intelligence and Natural Language", Vol. 930, https://doi. org/10.1007/978-3-030-01204-5_19 (26.01.2021).

Rodkin P. E. (2016), Media i socium. Tri popytki vskryt'sub\#ekt vlasti: Kriticheskij ocherk, Moskva.

Safronov A. P. (2018), Industrial'nyj avtoritarizm: porjadok social'nogo prinuzhdenija, Moskva.

Srnicek N. (2019), Kapitalizm platform, Moskva.

Suchman L. (2019), Rekonfiguracija otnoshenij chelovek - mashina: plany i situativnye dejstvija, Moskva.

Volodenkov S. V. (2019), Influence of Internet communication technologies on contemporary social and political processes: scenarios, challenges, and actors, "Monitoring of Public Opinion: Economic and Social Changes", No. 5, https://doi.org/10.14515/monitoring.2019.5.16 (26.01.2021).

Waddel K. (2018), The impending war over deepfakes, https://www.axios.com/the-impending-warover-deepfakes-b3427757-2ed7-4fbc-9edb-45e461eb87ba.html (26.01.2021).

Watson P. J., Jones A. (2013), Google-Berg: Global Elite Transforms Itself for Technocratic Revolution, https://archives.infowars.com/google-berg-global-elite-transforms-itself-for-technocratic-revolution/ (26.01.2021). 
Wong K. L. X., Dobson A. S. (2019), We're Just Data: Exploring China's Social Credit System in Relation to Digital Platform Ratings Cultures in Westernised Democracies, "Global Media and China", Vol. 4, No. 2, https://doi.org/10.1177/2059436419856090 (20.07.2021).

Xu Y. (2018), Programmatic Dreams: Technographic Inquiry into Censorship of Chinese Chatbots, "Social Media + Society", Vol. 4, No. 4, https://doi.org/10.1177/2056305118808780 (26.01.2021).

Zandbergen D., Uitermark J. (2020), In Search of the Smart Citizen: Republican and Cybernetic Citizenship in the Smart City, "Urban Studies", Vol. 57, No. 8, https://doi. org/10.1177/0042098019847410 (20.07.2021).

Zhukov D. S. (2020), Iskusstvennyj intellekt dlja obshhestvenno-gosudarstvennogo organizma: budushhee uzhe startovalo v Kitae, "Zhurnal Politicheskih Issledovanij”, Vol. 4, No. 2.

\begin{abstract}
The purpose of this article is to identify the risks, threats, and challenges associated with possible social changes in the processes of digitalization of society and transformations of traditional communication practices, which is associated with the emergence of new digital subjects of mass public communication that form the pseudo structure of digital interaction of people. The primary tasks of the work were to identify the potential of artificial intelligence technologies and neural networks in the field of social and political communications, as well as to analyze the features of "smart" communications in terms of their subjectness. As a methodological optics, the work used the method of discourse analysis of scientific research devoted to the implementation and application of artificial intelligence technologies and self-learning neural networks in the processes of social and political digitalization, as well as the method of critical analysis of current communication practices in the socio-political sphere. At the same time, when analyzing the current digitalization practices, the case study method was used. The authors substantiate the thesis that introducing technological solutions based on artificial intelligence algorithms and self-learning neural networks into contemporary processes of socio-political communication creates the potential for a wide range of challenges, threats, and risks, the key of which is the problem of identifying the actual subjects of digital communication acts. The article also discusses the problem of increasing the manipulative potential of "smart" communications, for which the authors used the concepts of cyber simulacrum and information capsule developed by them. The paper shows that artificial intelligence and self-learning neural network algorithms, being increasingly widely introduced into the current practice of contemporary digital communications, form a high potential for information and communication impact on the mass consciousness from technological solutions that no longer require control by operators - humans. As a result, conditions arise to form a hybrid socio-technical reality - a communication reality of a new type with mixed subjectness. The paper also concludes that in the current practices of social interactions in the digital space, a person faces a new phenomenon - interfaceization, within which self-communication stimulates the universalization and standardization of digital behavior, creating, disseminating, strengthening, and imposing special digital rituals. In the article, the authors suggest that digital rituals blur the line between the activity of digital avatars based on artificial intelligence and the activity of actual people, resulting in the potential for a person to lose his own subjectness in the digital communications space.
\end{abstract}

Keywords: the subject of communication, digital communication, mass consciousness, artificial intelligence, neural network algorithms, digital society, the transformation of social practices, hybrid subjectness. 


\title{
TEMATYKA KOMUNIKACJI CYFROWEJ W KONTEKŚCIE EWOLUCJI TECH- NOLOGICZNEJ WSPÓLCZESNEGO SPOLECZEŃSTWA:
}

\author{
ZAGROŻENIA, WYZWANIA, RYZYKA
}

\begin{abstract}
STRESZCZENIE
Celem niniejszego artykułu jest identyfikacja ryzyk, zagrożeń i wyzwań związanych z możliwymi zmianami społecznymi w procesach cyfryzacji społeczeństwa oraz przekształceniami tradycyjnych praktyk komunikacyjnych, co wiąże się z pojawieniem się nowych cyfrowych podmiotów masowej komunikacji publicznej tworzących pseudostrukturę cyfrowej interakcji pomiędzy ludźmi. Podstawowymi zadaniami pracy była identyfikacja potencjału technologii sztucznej inteligencji i sieci neuronowych w obszarze komunikacji społecznej i politycznej, a także analiza cech komunikacji ,inteligentnej” pod kątem jej podmiotowości. Jako optykę metodologiczną w pracy wykorzystano metodę analizy dyskursu badań naukowych poświęconych wdrożeniu i zastosowaniu technologii sztucznej inteligencji oraz samouczących się sieci neuronowych w procesach cyfryzacji społecznej i politycznej, a także metodę krytycznej analizy aktualnych praktyk komunikacyjnych w sferze społeczno-politycznej. Jednocześnie przy analizie aktualnych praktyk digitalizacyjnych zastosowano metodę studium przypadku. Autorzy uzasadniają tezę, że wprowadzenie do współczesnych procesów komunikacji społeczno-politycznej rozwiązań technologicznych opartych na algorytmach sztucznej inteligencji i samouczących się sieciach neuronowych stwarza potencjał dla szerokiego wachlarza wyzwań, zagrożeń i ryzyka, których kluczem jest problem identyfikacji rzeczywistych podmiotów aktów komunikacji cyfrowej. W artykule omówiono również problem zwiększenia potencjału manipulacyjnego ,inteligentnej” komunikacji, do czego autorzy wykorzystali opracowane przez siebie koncepcje cyber simulacrum i kapsuły informacyjnej. Artykuł pokazuje, że sztuczna inteligencja i samouczące się algorytmy sieci neuronowych, coraz szerzej wprowadzane do obecnej praktyki współczesnej komunikacji cyfrowej, stwarzają duży potencjał oddziaływania informacyjno-komunikacyjnego na świadomość masową z rozwiązań technologicznych, które nie wymagają już kontroli przez operatorów - ludzi. W efekcie powstają warunki do uformowania hybrydowej rzeczywistości społeczno-technicznej - rzeczywistości komunikacyjnej nowego typu o mieszanej podmiotowości. W artykule stwierdzono również, że w obecnych praktykach interakcji społecznych w przestrzeni cyfrowej człowiek staje przed nowym zjawiskiem - interfaceization, w ramach którego autokomunikacja stymuluje uniwersalizację i standaryzację zachowań cyfrowych, tworzenie, rozpowszechnianie, wzmacnianie i narzucanie szczególnego cyfrowego rytuału. W artykule autorzy sugerują, że cyfrowe rytuały zacierają granicę między aktywnością cyfrowych awatarów opartych na sztucznej inteligencji a aktywnością rzeczywistych ludzi, co skutkuje możliwością utraty przez człowieka własnej podmiotowości w cyfrowej przestrzeni komunikacyjnej.
\end{abstract}

Słowa kluczowe: podmiot komunikacji, komunikacja cyfrowa, świadomość masowa, sztuczna inteligencja, algorytmy sieci neuronowych, społeczeństwo cyfrowe, transformacja praktyk społecznych, podmiotowość hybrydowa 